\title{
Modulation of CYP1A1 by PKC Inhibitors and TPA Pre-Treatments in MH1C1 Rat Hepatoma Cells Exposed to 3 -Methylcholanthrene
}

\author{
Clara De Pascale, Cinzia Domenicotti, Mariapaola Nitti, Barbara Marengo, Mariafrancesca \\ Catalano, Chiara Scanarotti, Roberta Sanguineti, Maura Siri, Sabina Ledda, Susanna Penco \\ and Anna M. Bassi*
}

Department of Experimental Medicine, Section of General Pathology, University of Genova, Italy

\begin{abstract}
Cytochrome P4501A1 (CYP1A1), an enzyme known to metabolize polycyclic aromatic hydrocarbons, is regulated by the aryl hydrocarbon receptor (AhR). The involvement of protein kinase $\mathrm{C}$ (PKC) in the regulation of AhR signal transduction pathway, has been widely studied but the role of specific PKC isoform(s) involved in this process it is not well clarified. To study which PKC isoform(s) is implicated in the regulation of CYP1A1, in the poorly tumorigenic MH1C1 rat hepatoma cells, we examined the effects of some PKC pharmacological inhibitors, Calphostin C (CAL), Staurosporine (STA) and H7, and of 12-0-tetradecanoyl phorbol 13-acetate (TPA), a PKC activator, on basal and 3methylcholanthrene (MC)-induced CYP1A1 protein expression and mediated ethoxyresorufin O-deethylation (EROD) activity. In parallel, the activities of PKC- $\alpha,-\beta \mathrm{I},-\delta$ and $-\varepsilon$ isoforms, the most expressed in MH1C1 cells, were monitored. After pre-treatment with CAL, STA and H7, the MC-induced CYP1A1 protein and EROD activity were rapidly reduced with temporal profile similar to the profile of the activity of $\alpha$ and $\beta 1$ PKC isoforms. Moreover, TPA pre-treatment induced a biphasic effect on EROD activity, and a decline of PKC $-\beta$ I and $-\alpha$, in first instance, and $-\delta$ and $-\varepsilon$ activities later on. These findings clearly show that, in MH1C1 cells, PKC is involved in CYP1A1 regulation and that $\alpha$ and $\beta \mathrm{I}$ classic $\mathrm{PKC}$ isoforms play an active role in modulating this process.
\end{abstract}

Key Words: CYP1A1, PKC, TPA, PKC inhibitors, rat hepatoma cell line, in vitro.

\section{INTRODUCTION}

Among cytochrome P450s (CYPs) one of the most widely studied is the CYP1A1 isoenzyme, that despite its low expression level in many tissues, is highly inducible by polycyclic aromatic hydrocarbons (PAHs) and is able of bioactivating a large number of xenobiotics to toxic derivatives [1-4].

Mechanisms of CYP1A1 induction by the products of the aryl hydrocarbon (Ah)-inducible gene battery, have been widely studied, as reviewed by Whitlock in 1999 [5]. Ahreceptor (AhR) is a member of the basic helix-loop-helix / Per-Arnt-Sim (bHLH/PAS) family of transcription factors [6]. Unliganded AhR exists in a complex with heat shock protein 90 (HSP90), the HSP90 co-chaperone p23, and a hepatitis B virus X-associated protein 2 (XAP2) in the cytoplasm [7-10]. Upon ligand binding, i.e. PAH, activated AhR is translocated from the cytoplasm into the nucleus where dimerizes with AhR nuclear translocator (Arnt). The AhR/ Arnt heterodimer binds to a specific DNA element termed the xenobiotic response element (XRE), in the transcriptional regulatory region to regulate the transcription of $\mathrm{AhR}$ target genes including CYP1A1, CYP1A2, CYP1B1, and AhR repressor genes [11-13].

"Address correspondence to this author at Department of Experimental Pathology, General Pathology Section, University of Genova, via L.B. Alberti 2, I-16132 Genova Italy : E-mail: ambassi@medicina.unige.it
Since AhR and Arnt are both phosphorylated on threonine residues, it was suggested that serine/threonine kinases may be directly or indirectly involved in the functional regulation of these proteins. Variety of data obtained from in vitro experiments, whole-animal studies, and eukaryotic cell culture experiments have demonstrated that the serine/ threonine kinase PKC plays an important role in the regulation of the AhR signal transduction pathway, and its activity is required for nuclear events in the CYP1A1 transcriptional pathway [14-20].

PKCs are a family of homologous enzymatic isoforms implicated in a wide range of cellular functions, being involved in the transduction of signals for cell proliferation, differentiation and apoptosis. PKC isoforms are broadly subdivided into three subfamilies: classical (cPKC, $\alpha, \beta I, \beta I I, \gamma)$, calcium $\left(\mathrm{Ca}^{2+}\right)$ dependent and stimulated by second messenger diacylglycerol (DAG); novel (nPKC, $\delta, \varepsilon, \eta$ and $\theta$ ) $\mathrm{Ca}^{2+}$ independent but stimulated by DAG; and atypical (aPKC, $1, \zeta$ and $\lambda$ ) which require neither $\mathrm{Ca}^{2+}$ nor DAG for optimal activity [21]. PKC role in CYP induction is not clearly explained but several studies, however, have revealed that AhR-dependent and PKC-directed induction of CYPIAl and CYP1A2 genes exist, with differences regarding cell type and tissue $[14,22,23]$ and consequently, it is possible to hypothesize a cell type related expression of the dioxinresponsive genes. Further investigations have demonstrated that PKC activity is required for AhR-mediated signal transduction $[18,24,25]$ in order to influence the receptivity of 
AhR to ligand and /or the entry of liganded AHR into the nucleus [5, 7, 26]. Moreover, the differences in such responses might be also due to differential expression of PKC isoforms in various tissues [27].

An in vitro study has reported a stimulation of 2,3,7,8tetrachlorodibenzo-p-dioxin (TCDD) mediated induction of CYP1A1, when PKC was activated by phorbol esters, and a suppression of TCDD-mediated induction of CYP1A1 [18], after exposure to Staurosporine (STA), a PKC-inhibitor. Moreover, Machemer and Tukey (2005) demonstrated that a dose-dependent inhibition of PKC activity by Staurosporine was concordant with inhibition of TCDD-induced CYP1A1luciferase activity and although, in the same study, some PKC inhibitors such as GF109203X, Gö 6983, and Gö 6976, blocked PKC activity at concentrations independent of those necessary to inhibit TCDD induction of CYP1A1-luciferase activity, it has clearly shown the involvement of PKC at some level of the pathway and how the effect can be isoform specific [28].

Taken together, these findings do not clarify whether PKC direct interaction (i.e, PKC phosphorylates the AhR and/or CYP1A1 directly), or whether PKC-mediated phosphorylation of another intracellular signaling components led to an indirect induction on CYP1A1. Several studies indicate that PKC plays an important role in cellular communication by relaying signaling events upstream of phospholipid hydrolysis to downstream kinases such as MAP kinase and AP1 complex. Interactions between MAP kinase activity and regulation of the AhR-Arnt heterodimer complex - CYP1A1 induction [29-34] have been reported and AP-1 activity has been shown to be induced by AhR ligands $[35,36]$.

In our previous papers, we demonstrated that the well differentiated, poorly tumorigenic $\mathrm{MH} 1 \mathrm{C} 1$ rat hepatoma cell line is highly responsive to classical CYP1A1 inducers [3739], such as 3-methylcholanthrene (MC); it was also reported that MH1C1 cells express PKC- $\alpha,-\beta,-\delta$ and $-\varepsilon$ isoforms, and that their proliferation rate is $\mathrm{PKC}-\alpha$ and not PKC- $\varepsilon$-dependent [40, 41].

Aim of present study is to verify basal and MC-induced CYP1A1 protein expression and catalytic activity in MH1C1 cells, after exposure to some pharmacological inhibitors for PKC, such as STA, a broad spectrum PKC inhibitor, Calphostin $\mathrm{C}(\mathrm{CAL})$, an inhibitor of PKC- $\alpha,-\beta$ and $-\gamma, \mathrm{H} 7$, a PKC- $\alpha$ inhibitor, and to 12-O-Tetradecanoyl phorbol 13acetate (TPA), a protein kinase $\mathrm{C}$ activator. Furthermore, to determine which isoform(s) of PKC could be involved in the regulation of AhR signaling pathway, we have monitored the protein expression levels and activities of most expressed PKC isoforms, $-\alpha,-\beta,-\delta$ and $-\varepsilon$, during CYP1A1 induction.

\section{MATERIALS AND METHODOLOGY}

\section{Chemicals}

Culture medium (Dulbecco's modified Eagle's/Ham's F12, 1:1, DMEM/F12), fetal bovine serum (FBS), trypsinEDTA and saline solutions, neutral red, dimethyl sulfoxide (DMSO), MC, CAL, STA, H7, TPA, 7-ethoxyresorufin, dicumarol, $\beta$-glucuronidase/arylsulphatase (Type I), $\beta$-mercap- toethanol, leupeptin, phenylmethylsulphonylfluoride (PMSF) were purchased from Sigma Aldrich (Milan, Italy); PVDF membranes (Hybond-P), Enhanced Western Blotting Analysis System (ECL) and polyclonal secondary antibodies were supplied by GE Healthcare (Amersham, Bucks, U.K.). Polyclonal antisera specific for PKC isoforms were from Santa Cruz Biotechnology, (Santa Cruz, CA, USA). Anti-CYP1A1 antibody was obtained by OXYgene (Dallas, TX, USA). Bradford reagent dye concentrate was obtained from BioRad (Hercules, CA). All other chemicals and reagents were of the highest purity available and were purchased from Merck (Darmstadt, Germany).

\section{CELL LINE}

The rat hepatoma cell line MH1C1, obtained from Intelab Cell Line Collection (ICLC, IST, Genoa, Italy) was maintained in DMEM/F12(1:1) medium supplemented with $7 \%$ FBS in a humidified atmosphere with $5 \% \mathrm{CO}_{2}$. The medium was changed every 2-3 days. The cells were subcultured by trypsin-EDTA treatment. The cell cultures, periodically checked, resulted mycoplasma-free, using the DNA fluorochrome staining method with bis-benzamide dye (Hoechst 33258) and were at the 50-60 subcultures.

\section{CELL TREATMENTS}

MH1C1 cells were seeded 24 hours before the treatments in 96 and 24 well plates or in $75 \mathrm{~cm}^{2}$ flasks $\left(5 \times 10^{4}, 1 \times 10^{5}\right.$ or $1 \times 10^{6}$ cells, respectively) for the evaluation in semi-confluent cultures of cytotoxicity, CYP1A1-mediated catalytic activity and immunoreactive proteins, respectively. Before addition to the serum-free medium, CAL, H7, STA, TPA and MC were dissolved in DMSO, which was at a final concentration not exceeding $0.2 \%$ (used in the solvent controls). To compare the effects of the treatments in both basal and induced conditions, the cultures were exposed in triplicate for 2 hours to CAL, STA and $\mathrm{H} 7$ at various concentrations, whereas the treatment with $100 \mathrm{nM}$ TPA lasted 1, 6, 9, 12 and 24 hours, and then exposed for further 24 hours to DMSO alone or to the CYP1A1 inducer $10 \mu \mathrm{M} \mathrm{MC}$, dissolved in the medium still containing the previous compounds.

\section{CELL VIABILITY}

In order to define the non toxic concentration for each chemical compound, cell viability was assessed by means of the neutral red uptake (NRU) assay, according to the method of Borenfreund et al. [42]. After incubation for 3 hours at $37^{\circ} \mathrm{C}$ in a neutral red dye containing medium $(50 \mu \mathrm{g} / \mathrm{ml})$, the cells were washed twice in PBS solution and fixed by the procedure described by Riddell et al. [43]. The plates were then left at room temperature for $10 \mathrm{~min}$ and the absorbance of the extracted neutral red dye was read at $550 \mathrm{~nm}$ in a Uniskan II microplate reader (Labsystems, Helsinki, Finland).

\section{PROTEIN DETERMINATION}

Protein content of cell lysates was determined by the BioRad reagent protein assay [44], using bovine serum albumin as standard. 


\section{CYP1A1 CATALYTIC ACTIVITY}

The CYP1A1-dependent 7-ethoxyresorufin O-deethylase (EROD) activity was determined by a fluorometric assay [45], with minor modifications as described elsewhere [39]. After experimental treatments, monolayers were exposed for 1 hour to a serum-free culture medium containing $10 \mu \mathrm{M}$ dicoumarol and $8 \mu \mathrm{M}$ ethoxyresorufin; after hydrolysis of resorufin-conjugates with $\beta$-glucuronidase/arylsulphatase and extraction with methanol, the fluorescence was measured using a Perkin-Elmer LS-5 (Beaconsfield, UK) spectrofluorometer with excitation and emission wavelengths of 530 and $585 \mathrm{~nm}$, respectively. The level of resorufin was evaluated by comparison with a standard solution and expressed as $\mathrm{pmol} / \mathrm{min} / \mathrm{mg}$ protein.

\section{TOTAL CELL LYSATE}

After removal of the experimental medium, the monolayers were washed twice with cold Hank's balanced solution, and scraped in cold lysis buffer (10 mM HEPES, $\mathrm{pH} 7.5$, $0.25 \mathrm{M}$ sucrose, $5 \mathrm{mM}$ EDTA, $10 \mathrm{mM} \beta$-mercaptoethanol , 2 $\mathrm{mM}$ PMSF , $1 \mathrm{mM}$ leupeptin and $0.2 \%$ Triton X-100). Cell suspensions were incubated for $25 \mathrm{~min}$ at $4^{\circ} \mathrm{C}$ prior to sonication at $50 \mathrm{~W}$ for $10 \mathrm{sec}$. Lysates were then centrifuged at $100,000 \mathrm{x} \mathrm{g}$ for $30 \mathrm{~min}$ and collected supernatants were stored at $-80^{\circ} \mathrm{C}$ for up to 7 days.

\section{WESTERN BLOT ANALYSIS}

Cell lysate proteins $(50 \mu \mathrm{g})$ were resolved on SDS-PAGE gels in a Mini-protean II Electrophoresis Cell (Bio-Rad), and electroblotted onto a Hybond membrane, according to the manufacturer (GE Healthcare). Blots were probed with each primary antibodies, followed by exposure to horseradish peroxidase-conjugated secondary antibody. The immunoreactive proteins were visualized using ECL detection reagent, according to the manufacturer's protocol. The intensities of the protein bands were analysed by densitometric analysis (Gel Doc 2000, Bio-Rad), followed by quantitation with Quantity One (Bio-Rad) software.

\section{PKC ACTIVITY ASSAY}

Classic and novel PKC isoforms were immunoprecipitated with specific antibodies and protein G-sepharose starting from $50 \mu \mathrm{g}$ of protein sample. The immunoprecipitates were washed three times in a PKC buffer $(10 \mathrm{mM}$ Tris $\mathrm{HCl}$, $150 \mathrm{mM} \mathrm{NaCl}, 10 \mathrm{mM} \mathrm{MgCl} 2$, and $0.5 \mathrm{mM}$ DTT). The activity assay of classic isoenzymes [46-48] was performed by adding $40 \mu \mathrm{l}$ of PKC buffer supplemented with $0.1 \mathrm{mM}$ ATP, $[\gamma 32 \mathrm{P}] \mathrm{ATP}(2 \mu \mathrm{Ci}$ per sample $), 1 \mu \mathrm{g}$ of phosphatidylserine, $0.4 \mu \mathrm{g}$ of dioleilglycerol, $0.5 \mathrm{mM} \mathrm{CaCl} 2$, and $10 \mu \mathrm{g}$ of histone $\mathrm{H} 1$ as substrate. The same reaction mixture without calcium was used to evaluate the activity of novel PKCs. The reaction was continued for $10 \mathrm{~min}$ at $30^{\circ} \mathrm{C}$, then stopped by addition of Laemmli sample buffer. After centrifugation, the reaction mixtures were loaded onto $12.5 \%$ SDSpolyacrilamide gel, which was dried and then exposed to an autoradiographic film for $24 \mathrm{~h}$. Relative intensity of phosphorylated substrates was measured by densitometric scanning of autoradiographs.

\section{STATISTICAL ANALYSIS}

Results are expressed as means \pm SEM of at least three independent experiments performed in triplicate. Significance was assessed by one-way analysis of variance (ANOVA) followed by Dunnet tests.

\section{RESULTS}

\section{Effects of the MC Exposure on MH1C1 Cell Viability and EROD Activity}

The 24 hours cell treatment with increasing MCconcentration doses (from 1 to $10 \mu \mathrm{M}$ ) did not show any significant impairment in cell viability, whereas EROD activity was significantly increased in a dose-dependent manner (Fig. 1, panel A). CYP1A1 induction after 24 hours treatment with $10 \mu \mathrm{M} \mathrm{MC}$, the concentration which gives the highest EROD specific activity levels without affecting viability, was confirmed by immunoblotting analysis of the protein level (Fig. 1, panel B).

\section{Evaluation of the Cytotoxicity After Pre-Treatments with PKC Inhibitors and TPA}

To evaluate the implication of PKC in AhR-dependent CYP1A1 induction, 2 hours pre-treatments with PKC inhibitors were performed. In order to be sure that the results obtained were due to PKC-dependent pathway inhibition or modulation and not to cytotoxic effects of the treatments, a careful choice of the concentration to use in the following experiments was done after evaluation of cell viability during exposure to increasing concentration of PKC inhibitors (Table 1).

Although, in some conditions, the cell viability decreased significantly, we considered cytotoxic only those concentrations able to decrease cell viability below $15 \%$ from the mean of all controls, as recommended by ECVAM (European Centre for the Validation of Alternative Methods, http://ecvam.jrc.it/).

Pre-treatments with CAL and STA reduced the cell viability by $14 \%$ and $12 \%$, but the values at the highest concentration $(100 \mathrm{nM})$ or in association with MC were always within the range of tolerance and therefore not considered cytotoxic.

H7 was cytotoxic at micromolar concentration with $21 \%$ and $32 \%$ reduction of cell viability, when used alone or in association with MC, respectively.

Cell exposure to TPA alone at the concentration range of 1 - $100 \mathrm{nM}$ did not reveal any cytotoxic effects (data not shown). 1, 6, 12 and 24 hours pre-treatments with $100 \mathrm{nM}$ TPA followed by exposure to solvent (control) or $10 \mu \mathrm{M} \mathrm{MC}$ for 24 hours did not exert cytotoxicity effects (Table 2) since cell viability never dropped below $88 \%$.

\section{Effects of PKC Inhibitors on CYP1A1 Induction in MH1C1 Cells}

Pre-exposure to different concentrations of PKC inhibitors did not influence basal EROD activity (Fig. 2, panel A), 
but when pre-treatments with STA, H7 and CAL were followed by 24 hours MC exposure, EROD activity was inhibited in a dose-dependent manner. Maximum concentrations equal to $100 \mathrm{nM}, 75 \mathrm{nM}$ and $50 \mu \mathrm{M}$ for CAL, STA and H7, respectively, were chosen to carry out the experiments, inconsequence of their ability to give a significant activity inhibition $(88,24$ and $55 \%$ reduction versus MC-treated cultures, respectively) together with a lower rate of cytotoxicity ( $85 \%$ of viability).

Inhibition of CYP1A1 induction, measured by EROD activity, was confirmed at protein level with immunoblotting experiments where the inducible expression level of the P450's isoenzyme was measured in basal and induced conditions with or without inhibitors. MC-treated cells clearly showed a decrease in protein expression level after pretreatment with PKC inhibitors, and in particular after CAL exposure (67\% reduction) (Fig. 2, panel B).

\section{Effects of TPA on CYP1A1 Induction in MH1C1 Cells}

In $\mathrm{MH} 1 \mathrm{C} 1$ cells $100 \mathrm{nM}$ TPA pre-treatment did not reveal any significant effect on CYP1A1 basal activity, during the exposure time-considered, 0-24 hours (Fig. 3, panel A).

Interestingly, TPA exerted a biphasic effect on MC-induced EROD activity: the enzymatic activity was dramatically decreased after 6 hour treatment with $65 \%$ reduction versus control (MC-treated cultures, time 0), a slow recovery, after 12 hours, (22\% reduction, versus control) and a stable plateau between 12 and 24 hours treatment. A parallel pattern was observed in CYP1A1 protein level by immunoblotting (Fig. 3, panel B).

\section{EFFECTS OF PKC INHIBITORS AND TPA ON KINASE ACTIVITY IN MC-TREATED CELLS}

Western blotting analysis confirmed that PKC$\alpha,-\beta \mathrm{I},-\delta,-\varepsilon$ isoforms are expressed in $\mathrm{MH} 1 \mathrm{C} 1$ cell lines, and no statistically significant changes were observed after treatment with $10 \mu \mathrm{M}$ MC (Fig. 4).

In order to identify which of these $\mathrm{PKC}$ isoforms is/are possibly involved in CYP1A1 AhR-dependent induction, in our in vitro model, we analyzed the activity of two classic $(\alpha$ and $\beta \mathrm{I}$ ) and two novel ( $\delta$ and $\varepsilon$ ) PKC isoforms. All of them are responsive to TPA and to PKC inhibitors to different extent (Figs. 5 and 6).

The enzymatic activities of classic and novel isoforms evaluated by immuno-precipitation, showed that in MCtreated cells, PKC- $\alpha$ and $-\beta$ I were more sensitive to inhibitor treatments with respectively 35 and $25 \%$ decrease of the activity in presence of CAL, $25 \%$ (PKC- $\alpha$ ) and 19\% (PKC$\beta \mathrm{I})$ decrease in presence of STA; and 35\% (PKC- $\alpha)$ and $22 \%$

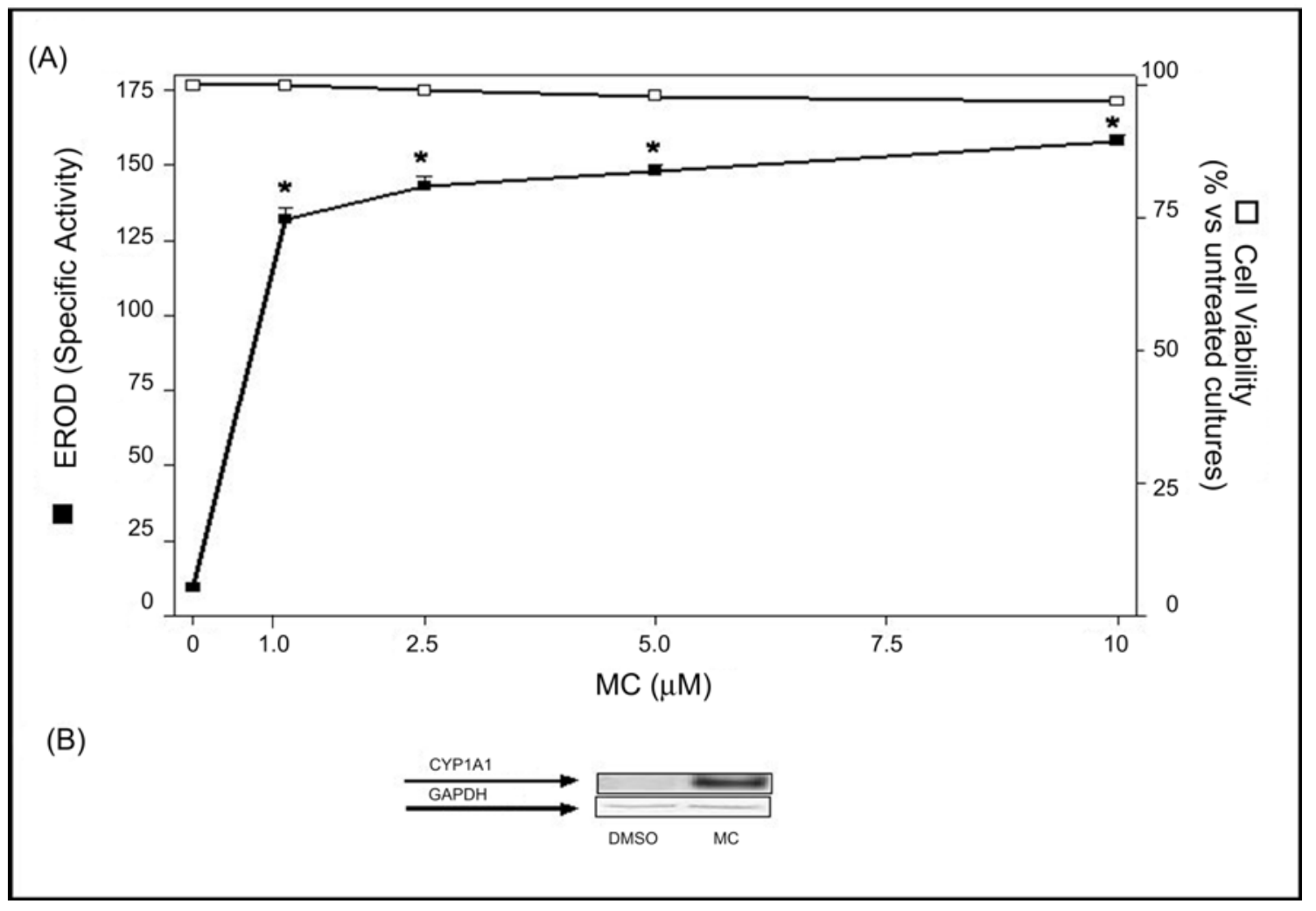

Fig. (1). Effects of MC exposure on MH1C1 cell viability and EROD activity.

Data represent EROD activity (pmol/min/mg protein) in samples treated with different concentrations of 1-2.5-10 $\mu \mathrm{M} \mathrm{MC,} \mathrm{(panel} \mathrm{A,} \mathrm{left}$ hand side) and the percentage of viability, extrapolated by NRU index, of MC treated samples versus DMSO, as un-induced control (panel A, right hand side). Values represent the means \pm SEM of 4 separate experiments run in triplicate. ${ }^{*}$, significantly different (p<0.001) vs value un-induced cultures (ANOVA test followed by Dunnett' post hoc test). Panel B, the immunoblots shown originate from one representative experiment of CYP $1 \mathrm{~A} 1$ protein induction after $24 \mathrm{~h}$ treatments with DMSO (control solvent) and $10 \mu \mathrm{M}$ MC. For further details, see Materials and Methodology. 
Table 1. Cytotoxicity of PKC Inhibitors on MH1C1 Rat Hepatoma Cells

\begin{tabular}{|c|c|c|c|}
\hline $\begin{array}{c}\text { PKC } \\
\text { Inhibitor }\end{array}$ & Conc & Un-Induced & MC - Induced \\
\hline \hline No & - & 100 & 100 \\
\hline \multirow{2}{*}{ CAL } & $1 \mathrm{nM}$ & $100 \pm 0.5$ & $89 \pm 2$. \\
& $10 \mathrm{nM}$ & $96 \pm 0.9$ & $98 \pm 1.21^{*}$ \\
& $25 \mathrm{nM}$ & $93 \pm 1.5$ & $87 \pm 0.9^{*}$ \\
& $50 \mathrm{nM}$ & $91 \pm 1.8$ & $86 \pm 1.2^{*}$ \\
\hline \multirow{3}{*}{ STA } & $100 \mathrm{nM}$ & $90 \pm 1.1$ & $98 \pm 2.3$ \\
& $1 \mathrm{nM}$ & $100 \pm 0.3$ & $97 \pm 2.1$ \\
& $5 \mathrm{nM}$ & $99 \pm 2.0$ & $96 \pm 0.8$ \\
& $10 \mathrm{nM}$ & $98 \pm 4.0$ & $96 \pm 0.7$ \\
& $75 \mathrm{nM}$ & $97 \pm 0.8$ & $85 \pm 2.1^{*}$ \\
& $100 \mathrm{nM}$ & $88 \pm 1.8^{*}$ & $99 \pm 1.0$ \\
& $5 \mu \mathrm{M}$ & $100 \pm 0.5$ & $92 \pm 1.8$ \\
& $10 \mu \mathrm{M}$ & $98 \pm 1.0$ & $89 \pm 1.3^{*}$ \\
& $25 \mu \mathrm{M}$ & $96 \pm 0.7$ & $85 \pm 2.1^{*}$ \\
& $50 \mu \mathrm{M}$ & $93 \pm 1.1^{*}$ & $68 \pm 1.4^{*}$ \\
\hline
\end{tabular}

MH1C1 cells were exposed to PKC inhibitors, CAL, STA and H7, for 2 hours and then for further $24 \mathrm{~h}$ to solvent alone (un-induced) or $10 \mu \mathrm{M}$ MC. Data are expressed as percentage of viability extrapolated by NRU index, versus untreated control cultures. Values represent the means \pm SEM of 4 separate experiments run in triplicate.

*, significantly different $(\mathrm{p}<0.001)$ vs un-induced cultures (ANOVA test followed by Dunnett' post hoc test). For further details, see Materials and Methodology.

Table 2. Time Dependent Effects of TPA Exposure on Viability of MH1C1 Rat Hepatoma Cells

\begin{tabular}{|c|c|c|}
\hline Time Exposure (Hours) & Un-Induced & MC - Induced \\
\hline \hline 0 & $100 \pm 0.5$ & $98 \pm 1.2$ \\
\hline 1 & $98 \pm 0.2$ & $97 \pm 0.8$ \\
\hline 6 & $97 \pm 1.1$ & $95 \pm 1.9^{*}$ \\
\hline 12 & $95 \pm 1.5^{*}$ & $89 \pm 1.2^{*}$ \\
\hline 24 & $92 \pm 1.8^{*}$ & $88 \pm 0.5^{*}$ \\
\hline
\end{tabular}

MH1C1 cells were exposed to TPA for 1-6-12-24 hours and then for further $24 \mathrm{~h}$ to DMSO alone (un-induced) or 10 $\mu \mathrm{M}$ MC. Data are expressed as percentage of viability extrapolated by NRU index, versus untreated control cultures. Values represent the means \pm SEM of 4 separate experiments run in triplicate.

*, significantly different ( $\mathrm{p}<0.001$ ) vs value un-induced cultures (ANOVA test followed by Dunnett' post hoc test). For further details, see Materials and Methodology.

(PKC- $\beta \mathrm{I}$ ) reduction after pre-treatment with $\mathrm{H} 7$. PKC- $\delta$ and $\varepsilon$, instead, were not deeply affected by any of the treatments.

The PKC activity was also measured in the presence of TPA, a well known tumoral promoting agent. As shown in Fig. 6, TPA induced time-related variations of classic and novel PKC isoform activities. Three hours pre-treatments with TPA decreased PKC- $\alpha$ and $-\beta$ I activity by $60 \%$. After 6 hours PKC- $\alpha$ was still inhibited to the same extent, whereas $\beta I$ activity recovered, reaching $78 \%$ of the control value (time 0). After 9 hour incubation PKC- $\alpha$ activity increased, reaching $70 \%$ of the control value (time 0 ) while $\beta \mathrm{I}$ maintained the same level. PKC- $\delta$ and $-\varepsilon$ activities were affected only after 6 hour pre-incubation with TPA, with a quick re covery of PKC- $\delta$ after 9 hours of treatment, whereas PKC- $\varepsilon$ decreased its activity $(<50 \%$ vs time 0$)$ in a time dependent manner.

\section{DISCUSSION}

Exposure to environmental contaminants, such as PAHs, leads to induction of cytochrome P450 1A1 and 1A2 [4955]. The process of transcriptional activation of these cytochromes involves different steps and proteins as a result of a ligand dependent activation. Among the different signaling process involved it is well known that PKC plays a role, although neither the mechanism nor the role of the different isoforms are completely understood.

$\mathrm{MH1C1}$ rat hepatoma cells represent a useful in vitro model because of their well-differentiated phenotype, and for their high responsiveness to classical CYP1A1 inducers [39, 56]. In this paper EROD activity specific to CYP1A1 [57] is evaluated in this cell line in basal and MC-induced conditions, and in the presence of TPA and PKC inhibitors; in parallel, the activities of $\mathrm{PKC}-\alpha,-\beta \mathrm{I},-\delta$ and $-\varepsilon$ isoforms are monitored. 


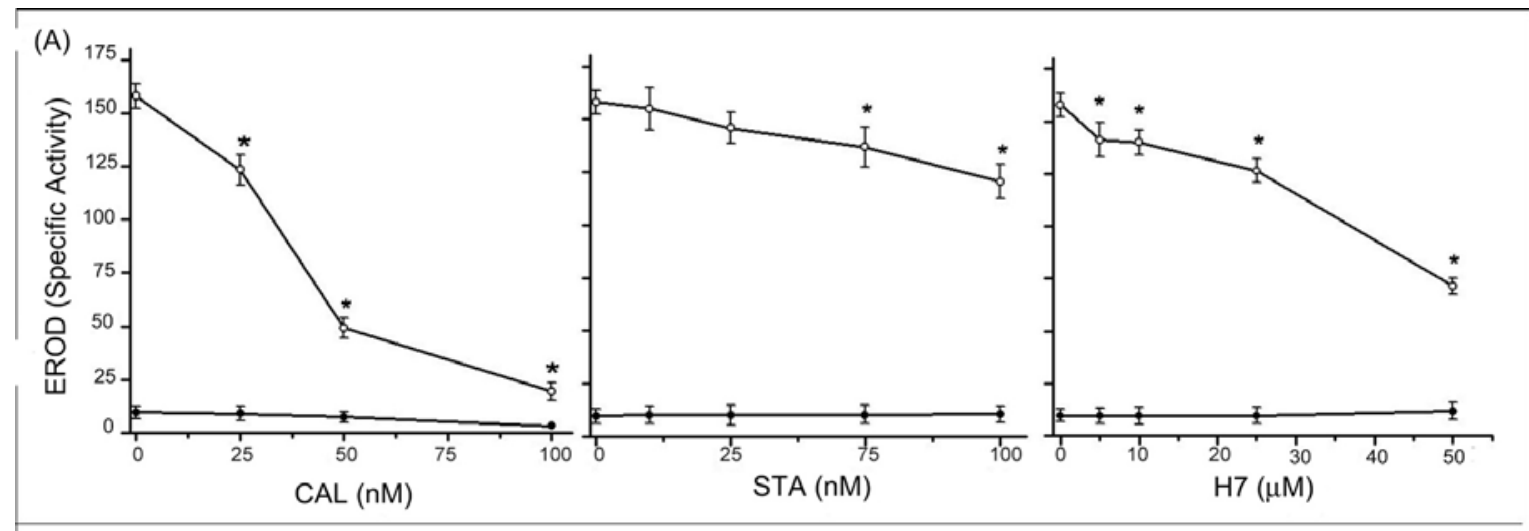

(B)

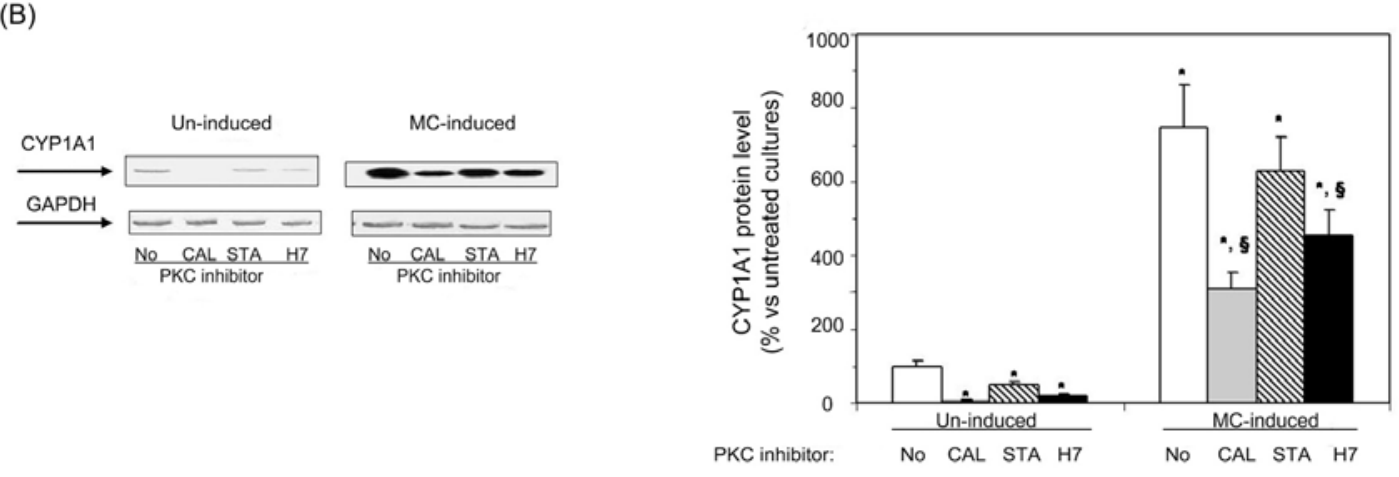

Fig. (2). Effects of PKC inhibitors on CYP1A induction in MH1C1.

Panel A: data represent EROD activity (pmol/min/mg protein) in samples treated for 2 hours with different concentrations of PKC inhibitor and for the last 24 hours in presence of solvent alone (un-induced) or $10 \mathrm{mM} \mathrm{MC} \mathrm{(empty} \mathrm{dots).} \mathrm{Values} \mathrm{represent} \mathrm{the} \mathrm{means} \pm$ SEM of 4 separate experiments run in triplicate. Panel B: On the left: the immunoblots shown originate from one representative, of 5 similar experiments, of CYP 1A1 protein induction after pre-treatment with $100 \mathrm{nM} \mathrm{CAL}, 75 \mathrm{nM}$ STA and $50 \mu \mathrm{M} \mathrm{H} 7$ and for the last 24 hours in presence of solvent (un-induced) or $10 \mu \mathrm{M}$ MC. On the right: the respective densitometric analysis of CYP1A1 protein. Data are expressed as means \pm SEM of 5 separate experiments; GAPDH was analysed as housekeeping gene. *, $\S \mathrm{p}<0.001$ vs respective un-treated control cultures and MC alone-treated cultures, respectively (test ANOVA followed by Dunnett's test). For further details, see Materials and Methodology.

(A)

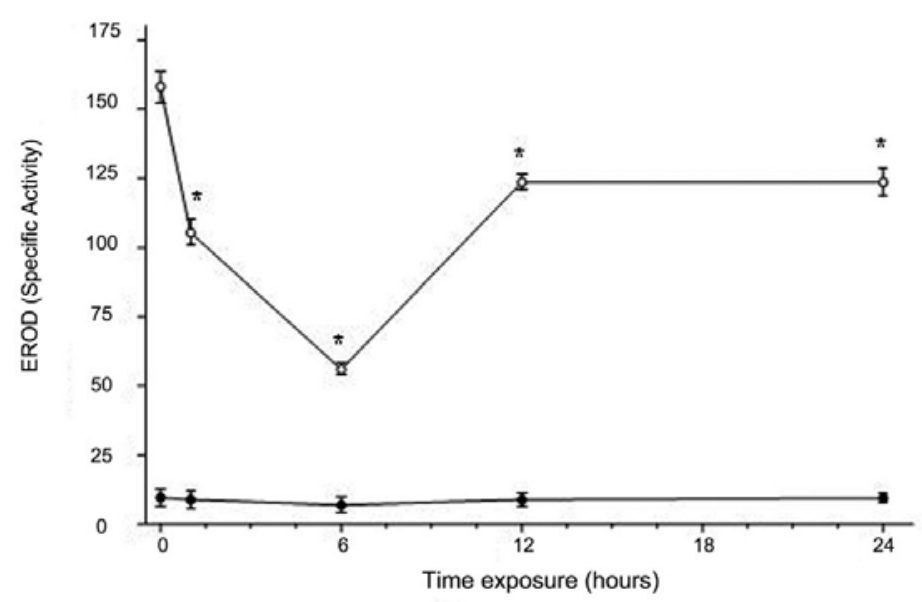

(B)
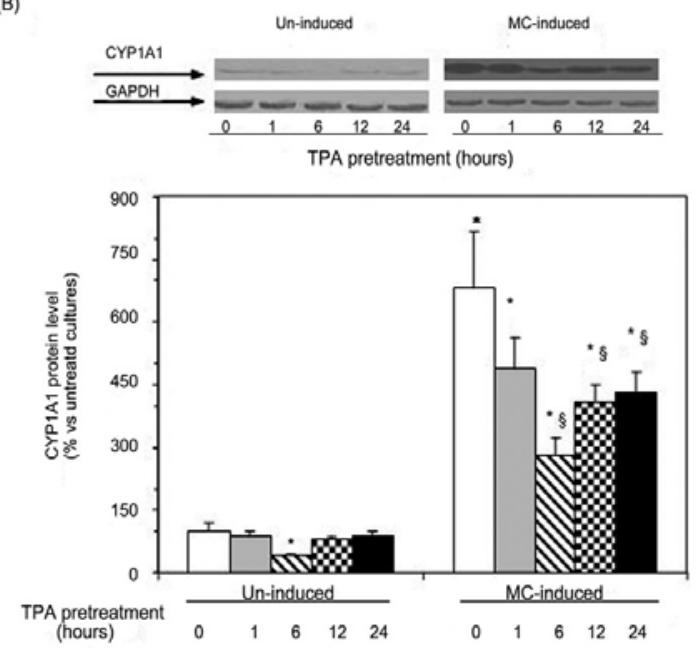

Fig. (3). Effect of TPA on CYP1A1 induction in MH1C1.

Panel A: data represent CYP 1A1 specific activity (EROD) (pmol/min/mg protein) in samples treated with 100 nM TPA alone for 0-1-6-12$24 \mathrm{~h}$ and for the last 24 hours in presence of solvent (un-induced, (full dots)), or $10 \mathrm{mM} \mathrm{MC} \mathrm{(empty} \mathrm{dots).} \mathrm{Values} \mathrm{represent} \mathrm{the} \mathrm{means} \pm$ SEM of 4 separate experiments run in triplicate. Panel B: The figure depicted represents the immunoblots shown originate from one representative experiment, of 5 similar experiments, of CYP 1A1 protein level in the same experimental conditions described above. In the lower part it was reported the respective densitometric analysis of CYP1A1 protein; GAPDH was analysed as housekeeping gene Data are expressed as means \pm SEM of 5 separate experiments. *, $\S \mathrm{p}<0.001$ vs respective un-treated control cultures and MC alone-treated cultures, respectively (test ANOVA followed by Dunnett's test). For further details, see Materials and Methodology. 


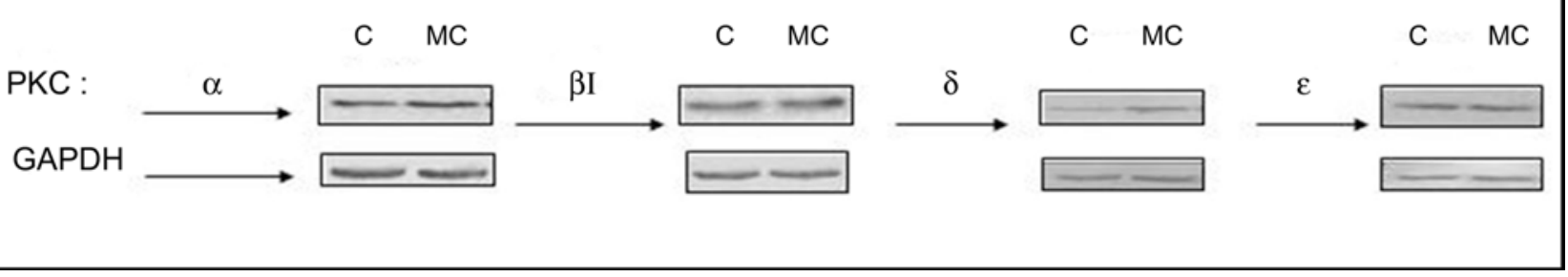

Fig. (4). PKC- $\alpha,-\beta \mathrm{I} .-\delta$ and $-\varepsilon$ protein levels in MH1C1 cells.

Western blotting was performed to analyse PKC- $\alpha,-\beta \mathrm{I},-\delta$ and $-\varepsilon$ isoform levels after $24 \mathrm{~h}$ treatment with solvent alone (C) or with $10 \mu \mathrm{M}$ MC. The immunoblots shown originate from one representative experiment among five independent experiments. Immunoreactive bands were quantified and the arbitrary units of all by densitometric analysis and normalized to GAPDH levels, and no significant differences were evidenced by ANOVA test followed by Dunnett' post hoc test.

(A)

$\operatorname{PKC} \alpha$

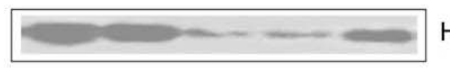

$\mathrm{HI}-21.5 \mathrm{kDa}$

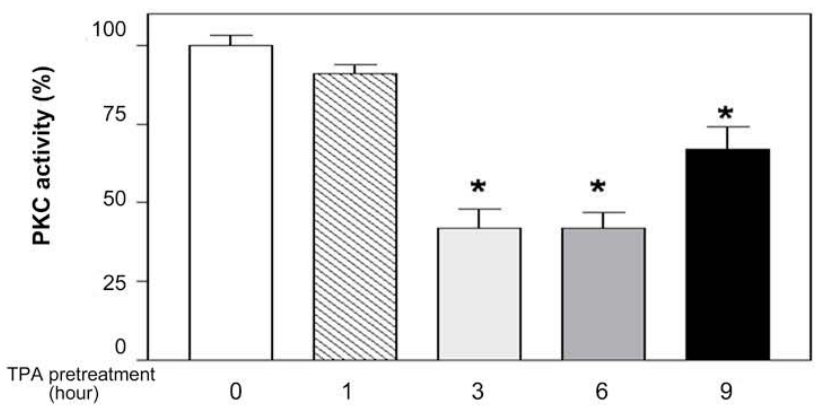

(C)
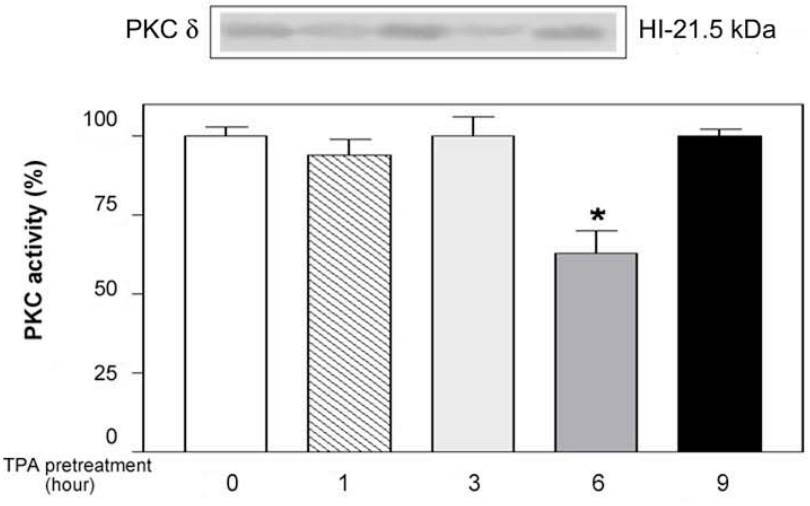

(B)

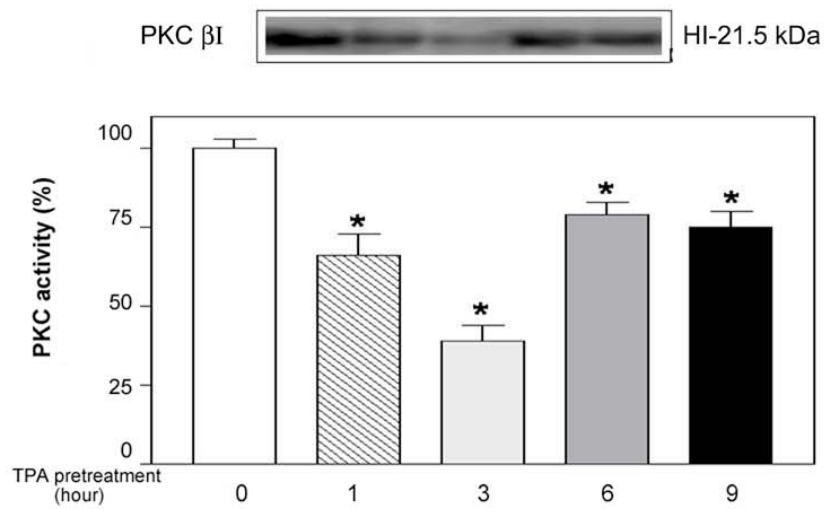

(D)
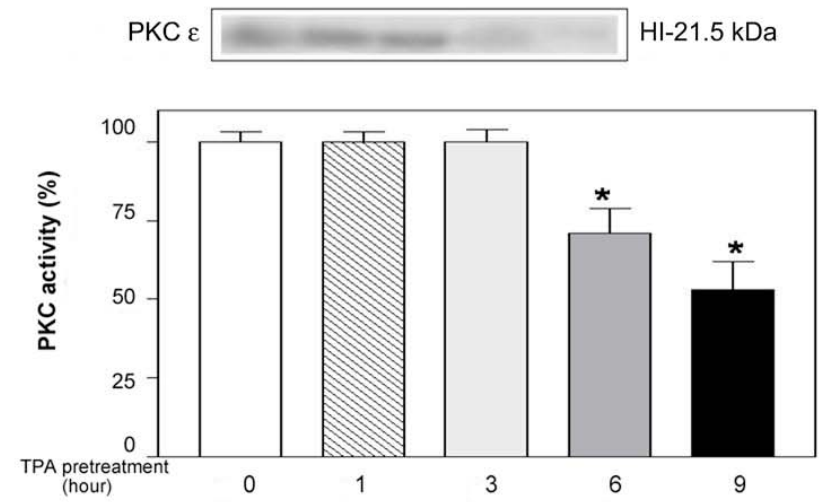

Fig. (5). PKC isoform activity in MH1C1 cells after exposure to PKC inhibitors and MC.

MH1C1 cell cultures were exposed to $10 \mu \mathrm{M}$ MC, for the last 24 hours, alone or after 2 hours pre-treatment with $100 \mathrm{nM}$ CAL, $75 \mathrm{nM}$ STA and $50 \mu \mathrm{M}$ H7. Classic ( $\alpha$ and $\beta \mathrm{I}$, Panel $\mathbf{A}$ and $\mathbf{B}$, respectively) and novel ( $\delta$ and $\varepsilon$, panel $\mathbf{C}$ and $\mathbf{D}$, respectively ). PKC isoenzymes were immuno-precipitated by specific antibodies and their enzymatic activities were assayed with $\mathrm{H} 1$ histone as substrate. Proteins were separated by SDS-PAGE, and H1 histone phosphorylation was detected by autoradiography. The autoradiograms shown, originate from one representative experiment. Phosphorylation of the substrate by PKC isoforms was quantified by densitometric analysis. The graph reports the arbitrary units of PKC isoenzyme activity expressed as mean \pm SEM of three separate experiments.

*, significantly different $(\mathrm{p}<0.001)$ vs value MC-induced cultures (ANOVA test followed by Dunnett' post hoc test).

The decrease in MC-induced EROD activity in presence of CAL, STA and $\mathrm{H} 7$ has been confirmed at the protein level with a clear inhibition of CYP1A1 at the concentrations of the inhibitors which modulate the kinase activity without toxic effects on the cells. These observations are consistent with many studies in the last decade which have reported the modulation mediated by PKC of CYP1A1 activity and expression in many cell types and tissues. A various number of data and papers on in vitro and in vivo studies suggest that serine/threonine kinase PKC plays an important role in the 
regulation of AhR signal transduction pathway $[14,15,23$, $25,58,59]$.

Our findings indicate an involvement of PKC in CYP$1 \mathrm{~A} 1$ induction by $\mathrm{MC}$, since pre-treatments with $\mathrm{PKC}$ inhibitors clearly abrogated CYP1A induction at the activity and protein level. Treatments with TPA show suppression of MC-induced CYP1A1, with a significant reduction of EROD specific activity in cells pre-treated for 6 hours with $100 \mathrm{nM}$ TPA prior MC addition (Figure 3, panel A). However, the level of reduction is time-dependent. In fact, after 12 hours the activity recovers by reaching $78 \%$ of value of the control (MC treated, time 0) and remains constant up to 24 hours. The biphasic effect of TPA on MC-induced CYP1A, was already demonstrated by Moore et al. [58] who found that TPA causes a time and concentration-dependent modulation of TCDD-induced CYP1A1 gene expression in MCF-7 cells.

The mechanism by which PKC is able to mediate CYP induction through $\mathrm{AhR}$ mediated signal-transduction has been extensively studied [15, 18, 24, 28, 60], and although significant contributions have made towards understanding this process, little is known about which specific PKC isoforms are involved in this process.

PKC $\alpha$
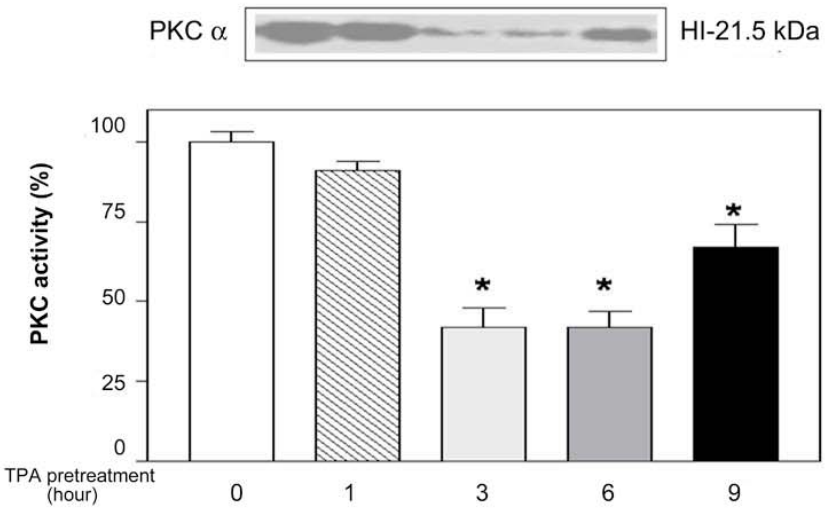

(C)
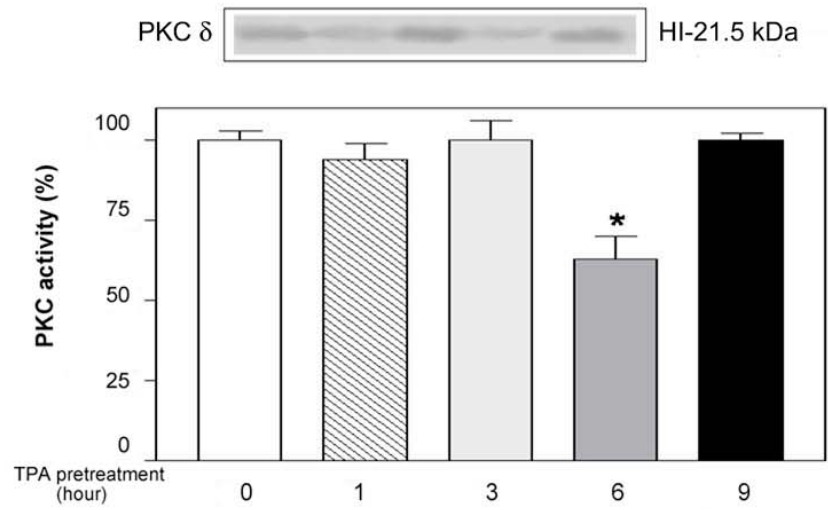

Analyzing data relative to down-regulation of CYP1A1 induction in the presence of PKC inhibitors and the activity of single isoenzymes, it is evident that CAL, counteracting CYP induction, causes a significant reduction in the activitys of $\alpha$ and $\beta \mathrm{I}$ isoforms of PKC (Fig. 5), thereby suggesting a possible involvement of classic PKC isoforms in the CYP1A1 regulation.

STA is less efficient in down-regulating PKC isoforms probably due to the lower specificity compared to other inhibitors. However, STA has been already shown to inhibit a variety of other kinases as well as PKC, including tyrosine kinases, protein kinase $\mathrm{A}$, protein $\mathrm{G}$, and calcium-calmodulin kinase [61-63]. Since after pre-treatments with PKC inhibitors, MC-induced EROD activity decreases in a dose- dependent manner, these data suggest a possible involvement of PKC or other STA-sensitive kinases in this process.

In our conditions we found an unresponsiveness of PKC$\delta$ and $-\varepsilon$ isoforms to any of the inhibitors tested; these results, indicate that the non-toxic doses of inhibitors are not prop-

(B)

PKC $\beta I$
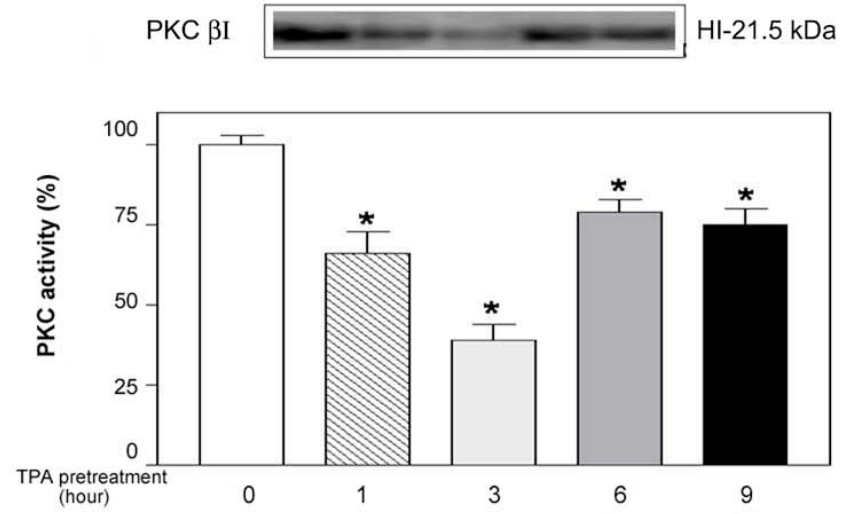

(D)
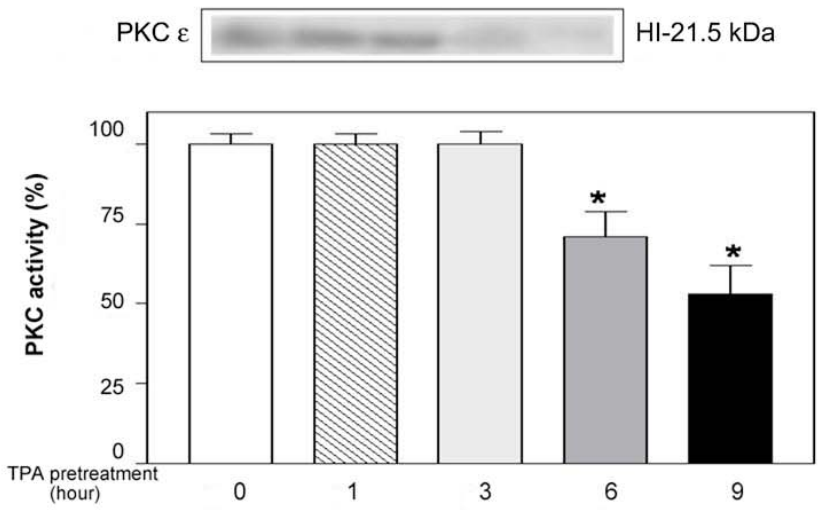

Fig. (6). PKC isoform activity in MH1C1 cells in presence of TPA and MC.

Cells were pre-treated with TPA for 0-1-3-6 and 9 hours and MC was added for the last $24 \mathrm{~h}$ of incubation. Classical ( $\alpha$ and $\beta$ I. Panel A and B respectively ) and novel ( $\delta$ and $\varepsilon$, Panel $\mathbf{C}$ and $\mathbf{D}$ respectively ) isoenzymes were immuno-precipitated by specific antibodies and their enzymatic activities were assayed with $\mathrm{H} 1$ histone as substrate. Proteins were separated by SDS-PAGE, and H1 histone phosphorylation was detected by autoradiography. The autoradiograms shown originate from one representative experiment. Phosphorylation of the substrate by PKC isoforms was quantified by densitometric analysis. The graph reports the arbitrary units of PKC isoenzyme activity expressed as mean \pm SEM of three separate experiments.

*, significantly different ( $\mathrm{p}<0.001)$ vs value MC-induced cultures (ANOVA test followed by Dunnett' post hoc test). 
erly efficient to inactivate novel isoforms in $\mathrm{MH} 1 \mathrm{C} 1$ cells and allow us to hypothesize a minor involvement of $\delta$ and $\varepsilon$ isoforms in CYP1A1 induction. In this direction, Machemer and Tukey [28] compared dose-response curves of a luciferase CYP1A1 reporter gene with PKC isoform IC50 values, in the presence of relatively specific inhibitors; they reported that treatments with Gö 6983 and GF109203X able to inhibit PKC- $\delta$ at different concentrations, did not block CYP1A1 luciferase activity and the inhibitor Gö 6976 able to block CYP 1A1 luciferase activity, did not inhibit PKC$\delta$; moreover, inhibitors blocking PKC- $\varepsilon$ activity, did not affect CYP1A1 luciferase activity. Therefore, these data suggest that PKC- $\delta$ and $-\varepsilon$ were not linked to regulation of CYP1A1 transcription.

TPA pre-treatment induced an early inhibition of CYP1A1 activity that is already appreciable after 1hour when PKC $\beta$ is inhibited by 30\%; moreover, after 6 hours TPA induced a maximal inhibition of CYP1A1 activity, determining at the same time a $65 \%$ decline in $\alpha, 30 \%$ in $\delta$ and $35 \%$ in $\varepsilon$ PKC activities (Figs. 4 and 6). It has been widely supported that treatment of cells with TPA, an activator of classic and novel PKC isozymes, leads to a plethora of responses in a strict cell-type-dependent specific manner [64]. In our context, the inhibition of MC-induced EROD activity is observed at later times of TPA pre-treatments, when PKC isoforms, both classic and novel, are down-regulated as demonstrated by the progressive loss of functional activities. In fact, TPA is able to induce translocation from cytosol to membrane and vice versa, and the down-regulation of PKC isoenzymes depends on the concentration and exposure time $[65,66]$.

Recent studies with transfected NCI-H295 cells, point out a PKC involvement in controlling CYP11B2 gene expression. After treatments with GF109203X, a PKC inhibitor, there was an increase in CYP11B2 promoter activity, whereas after TPA exposure the transcriptional activity was inhibited [67].

\section{CONCLUSIONS}

In summary this study shows that in $\mathrm{MH} 1 \mathrm{C} 1$ cells $\mathrm{PKC}$ is involved in CYP1A1 regulation and that classic PKC isoforms are more likely to be an active part of this process. Our data show that CAL, which is more efficient in counteracting CYP1A1 induction, is able to inhibit $\alpha$ and $\beta \mathrm{I}$ isoforms partially, and that TPA, which causes EROD activity inhibition, down-regulates $\mathrm{PKC}-\alpha$ and $\beta \mathrm{I}$ probably as a consequence of a quick activation of the kinases within few minutes, as also suggested by other studies [65-66]. Although the delayed effect of TPA on PKC- $\delta$ and $-\varepsilon$ doesn't exclude a possible implication of these novel isoenzymes, we can confirm the potential role of PKC- $\alpha$ and $-\beta$ I classical isoforms in the modulation of EROD activity, either through a direct action on CYP1A1 induction or via an indirect regulation of MAPK pathways. This study represents an interesting conceptual framework linking PKC mediated signal transduction to CYP1A1 induction, although further investigations in this direction are required.

\section{ACKNOWLEDGEMENT}

This work was supported in part by a grant for scientific research from the University of Genoa, and by a financial support from EQUIVITA, Animalisti Italiani and Movimento Ecologico Nazionale UNA. The authors have no financial relationships to declare. The authors are very grateful to Prof. Margherita Ferro for her valuable support and comments and to Jonathan Taylor for his helpful corrections.

$\begin{array}{ll}\text { ABBREVIATIONS } & \text { aryl hydrocarbon receptor } \\ \mathrm{AhR}= & \text { Calphostin } \mathrm{C} \\ \mathrm{CAL}= & \text { cytochrome P450 } \\ \mathrm{CYP}= & \text { 3-ethoxyresorufin O-deethylase } \\ \mathrm{EROD}= & \text { neutral red uptake test } \\ \mathrm{MC}= & \text { polycyclic aromatic hydrocarbons } \\ \mathrm{NRU}= & \text { staurosporine } \\ \mathrm{PAHs}= & \text { 2,3,7,8-tetrachlorodibenzo-p-dioxin } \\ \mathrm{PKC}= & 12-0 \text {-tetradecanoyl phorbol 13-acetate } \\ \text { STA } & =\end{array}$

\section{REFERENCES}

[1] Jones KW, Whitlock JP Jr. Functional analysis of the transcriptional promoter for the CYP 1A1 gene. Mol Cell Biol 1990; 10: 5098-105.

[2] Yanagida A, Sogawa K, Yasumoto KI, Fujii-Kuriyama Y. A novel cis-acting DNA element required for a high level of inducible expression of the rat P-450c gene. Mol Cell Biol 1990; 10:1470-5.

[3] Koch KS, Fletcher RG, Grond MP, et al. Inactivation of plasmid reporter gene expression by one benzo(a)pyrene-diol-epoxide DNA adduct in adult rate hepatocytes. Cancer Res 1993; 53: 2279-86.

[4] Schmalix WA, Maser H, Kiefer F, et al. Stable expression of human cytochrome P450 1A1 cDNA in V79 Chinese hamster cells and metodic activation of benzo(a)pyrene. Eur J Pharmacol 1993; 248: 251-61.

[5] Whitlock JJ. Induction of cytochrome P450 1A1. Annu Rev Pharmacol Toxicol 1999; 39: 103-25.

[6] Furness SG, Lees MJ, Whitelaw ML. The dioxin (aryl hydrocarbon) receptor as a model for adaptive responses of bHLH /PAS transcription factors. FEBS Lett 2007; 581: 3616-25.

[7] Meyer BK, Pray-Grant MG, Vanden Heuvel JP, Perdew GH. Hepatitis $\mathrm{B}$ virus $\mathrm{X}$-associated protein 2 is a subunit of the unliganded aryl hydrocarbon receptor core complex and exhibits transcriptional enhancer activity. Mol Cell Biol 1998; 18: 978-88.

[8] Meyer BK, Perdew GH. Characterization of the AhR-Hsp90-XAP2 core complex and the role of the immunophilin-related protein XAP2 in AhR stabilization. Biochemistry 1999; 38: 8907-17.

[9] Schmidt JV, Bradfield CA. Ah receptor signaling pathways. Annu Rev Cell Dev Biol 1996; 12: 55-89.

[10] Hankinson O. The aryl hydrocarbon receptor complex. Annu Rev Pharmacol Toxicol 1995; 35: 307-40.

[11] Fujii-Kuriyama Y, Mimura J. Molecular mechanisms of AhR function in the regulation of cytochrome P450 genes. Biochem Biophys Res Commun 2005; 338: 311-7.

[12] Mimura J, Ema M, Sogawa K, Fujii-Kuriyama Y. Identification of a novel mechanism of regulation of Ah (dioxin) receptor function. Genes Dev 1999; 13: 20-25.

[13] Dong L, Ma Q, Whitlock JP Jr. DNA binding by the heterodimeric Ah receptor. Relationship to dioxin-induced CYP1A1 transcription in vivo. J Biol Chem 1996; 271: 7942-48. 
[14] Berghard AK, Gradin I, Pongratz M, Whitelaw M, Poellinger L. Cross-coupling of signal transduction pathways: the dioxin receptor mediates induction of cytochrome P4501A1 expression via a protein kinase C-dependent mechanism. Mol Cell Biol 1993; 13: 67789.

[15] Butkiewicz D, Grzybowska E, Hemminki K, et al. Dioxindependent activation of murine CYP1A1 gene transcription requires protein kinase C-dependent phosphorylation. Mol Cell Biol 1992; 12: 1856-63.

[16] Mahon MJ, Gasiewicz TA. Ah receptor phosphorylation: localization of phosphorylation sites to the C-terminal half of the protein. Arch Biochem Biophys 1995; 318(1): 166-74.

[17] Pongratz I, Mason GGF, Poellinger L. Dual roles of the 90-kDa heat shock protein hsp90 in modulating functional activities of the dioxin receptor: evidence that dioxin receptor functionally belongs to a subclass of nuclear receptors which require hsp90 both for ligand binding activity and repression of intrinsic DNA binding activity. J Biol Chem 1992; 267: 133728-34.

[18] Chen YH, Tukey RH. Protein kinase C modulates regulation of the CYP1A1 gene by the aryl hydrocarbon receptor. J Biol Chem 1996; 271: 26261-6.

[19] Long,WP, Perdew GH. Lack of an absolute requirement for the native aryl hydrocarbon receptor (AhR) and AhR nuclear translocator transactivation domains in protein kinase C-mediated modulation of the AhR pathway. Arch Biochem Biophys 1999; 371: 24659 .

[20] Safe S, Wang F, Porter W, Duan R, McDougal A. Ah receptor agonists as endocrine disruptors: Antiestrogenic activity and mechanisms. Toxicol Lett 1998; 102-103: 343-7.

[21] Nishizuka Y. Intracellular signaling by hydrolysis of phospholipids and activation of protein kinase C. Science 1992; 258: 607-14.

[22] Reiners JJJr, Cantu AR, Scholler AP. Phorbol ester-mediated suppression of cytochrome P450 CYP1A1 induction in murine skin: involvement of protein kinase C. Biochem Biophys Res Commun 1992; 186: 970-6.

[23] Okino ST, Pendurthi UR, Tukey RH. Phorbol esters inhibit the dioxin receptor-mediated transcriptional activation of the mouse CYP1A1 and CYP1A2 genes by 2,3,7,8-tetrachlorodibenzo-pdioxin. J Biol Chem 1992; 267: 6991-8.

[24] Long WP, Pray-Grant M, Tsai JC, Perdew GH. Protein kinase C activity is required for aryl hydrocarbon receptor pathwaymediated signal transduction. Mol Pharmacol 1998; 53: 691-700.

[25] Ikegwuonu FI, Christou M, Jefcoate C. Regulation of cytochrome P4501B1 (CYP1B1) in mouse embryo fibroblast (C3H10T1/2) cells by protein kinase C (PKC). Biochem Pharmacol 1999; 57: 619-30.

[26] Carver LA, Bradfield CA. Ligand-dependent interaction of the aryl hydrocarbon receptor with a novel immunophilin homolog in vivo. J Biol Chem 1997; 272: 11452-6.

[27] Liu WS, Heckman CA. The sevenfold way of PKC regulation. Cell Signal 1998; 10: 529-42.

[28] Machemer DEW, Tukey RH. The role of protein kinase C in regulation of TCDD-mediated CYP1A1 gene expression. Toxicol Sci 2005; 87: 27-37.

[29] Buchner $\mathrm{K}$. The role of protein kinase $\mathrm{C}$ in the regulation of cell growth and in signaling to the cell nucleus. J Cancer Res Clin Oncol 2000; 126: 1-11.

[30] Andrieux L, Langouet S, Fautrel A, et al. Aryl hydrocarbon receptor activation and cytochrome P450 1A induction by the mitogenactivated protein kinase inhibitor U0126 in hepatocytes. Mol Pharmacol 2004; 65: 934-43.

[31] Tan Z, Huang M, Puga A, Xia Y. A critical role for MAP kinases in the control of Ah receptor complex activity. Toxicol Sci 2004; 82: 80-7.

[32] Brandlin I, Hubner S, Eiseler T, et al. Protein kinase C (PKC)etamediated PKC mu activation modulates ERK and JNK signal pathways. J Biol Chem 2002; 277: 6490-6496.

[33] Hausser A, Storz P, Hubner S, Braendlin I, Martinez-Moya M, Link G, Johannes FJ. Protein kinase C mu selectively activates the mitogen-activated protein kinase (MAPK) P42 pathway. FEBS Lett 2001; 492: 39-44.

[34] Yim S, Oh M, Choi SM, Park H. Inhibition of the MEK-1/P42 MAP kinase reduces aryl hydrocarbon receptor-DNA interactions. Biochem Biophys Res Commun 2004; 322: 9-16.

[35] Weber TJ, Ou X, Merchant M, Wang X, Safe SH, Ramos KS. Biphasic modulation of protein kinase $\mathrm{C}$ (PKC) activity by poly- chlorinated dibenzo-p-dioxins (PCDDs) in serum-deprived rat aortic smooth muscle cells. J Biochem Toxicol 1994; 9: 113-20.

[36] Wisdom R. AP-1: one switch for many signals. Exp Cell Res 1999; 253: $180-5$.

[37] Ferro M, Bassi AM, Marinari UM, et al. Induction of cytochrome(s) P450-dependent drug metabolism in cultured MH1C1 hepatoma cells. Cell Biochem Funct 1984; 2: 263-8.

[38] Ferro M, Marinari UM, Bassi AM, Nanni G. Biochemical properties of carcinogen-metabolizing enzymes in cultured hepatoma cells. Toxicol Pathol 1987; 15: 97-102.

[39] Donato MT, Bassi AM, Gomez-Lechon MJ, et al. Evaluation of the xenobiotic biotransformation capability of six rodent hepatoma cell lines in comparison with rat hepatocytes. "In Vitro" Cell Dev Biol Anim 1994; 30A: 574-80.

[40] Perletti GP, Smeraldi C, Porro D, Piccinini F. Involvement of the alpha isoenzyme of protein kinase $\mathrm{C}$ in the growth inhibition induced by phorbol esters in MH1C1 hepatoma cells. Biochem Biophys Res Commun 1994; 205: 1589-94.

[41] Perletti G, Tessitore L, Sesca E, Pani P, Dianzani MU, Piccinini F. Epsilon PKC acts like a marker of progressive malignancy in rat liver, but fails to enhance tumorigenesis in rat hepatoma cells in culture. Biochem Biophys Res Commun 1996; 221: 688-91

[42] Borenfreund E, Puerner JA. Toxicity determined "in vitro" by morphological alterations and neutral red absorbation. Toxicol Lett 1985; 24: 119-124.

[43] Riddell RJ, Clothier RH, Balls M. An evaluation of three "in vitro" cytotoxicity assays. Food Chem Toxicol 1986; 24: 469-71.

[44] Bradford MM. A rapid and sensitive method for the quantitation of microgram quantities of protein utilizing the principle of proteindye binding. Anal Biochem 1976; 72: 248-54.

[45] Burke MD, Thompson S, Elcombe CR, Halpert J, Haaparanta T, Mayer RT. Ethoxy-, pentoxy- and benzyloxy-phenoxazones and homologues: a series of substrates to distinguish between different induced cytochromes P-450. Biochem Pharmacol 1985; 34: 333745 .

[46] Pessino A, Passalacqua M, Sparatore B, Patrone M, Melloni E, Pontremoli S. Antisense oligodeoxynucleotide inhibition of protein kinase $\mathrm{C}$ expression accelerates induced differentiation of murine erythroleukaemia cells. Biochem J 1995; 312: 549-54.

[47] Konishi H, Tanaka M, Takemura Y, Matsuzaki H, Ono Y, Kikkawa U, Nishizuka $\mathrm{Y}$. Activation of protein kinase $\mathrm{C}$ by tyrosine phosphorylation in response to $\mathrm{H}_{2} \mathrm{O}_{2}$. Proc Natl Acad Sci USA 1997; 91: 11233-37.

[48] Traub O, Monia BP, Dean MN, Berk BC. PKC-var epsilon is required for mechano-sensitive activation of ERK1/2 in endothelial cells. J Biol Chem 1997; 272: 31251-7.

[49] Gelboin HV. Benzo[a]pyrene metabolism, activation, and carcinogenesis: role and regulation of mixed function oxidases and related enzymes. Physiol Rev 1980; 60: 1107-66.

[50] Whitlock JP Jr. The regulation of cytochrome P-450 gene expression. Annu Rev Pharmacol Toxicol 1986; 26: 333-69.

[51] ShimadaT, Martin MV, Pruess-Schwartz D, Marnett LJ, Guengerich FP. Roles of individual human cytochrome P-450 enzymes in the bioactivation of benzo[a]pyrene, 7,8-dihydroxy-7,8-dihydrobenzo[a]pyrene, and other dihydrodiol derivatives of polycyclic aromatic hydrocarbons. Cancer Res 1989; 49: 6304-12.

[52] Denison MS, Whitlock JP Jr. Xenobiotic-inducible transcription of cytochrome P450 genes. Biol Chem 1995; 270: 18175-18178.

[53] Shimada T, Hayes CL, Yamazaki H, et al. Activation of chemically diverse procarcinogens by human cytochrome P450 1B1. Cancer Res 1996; 56: 2979-84.

[54] Sjogren M, Ehrenberg L, Rannug U. Relevance of different biological assays in assessing initiating and promoting properties of polycyclic aromatic hydrocarbons with respect to carcinogenic potency. Mutat Res 1996; 358: 97-112.

[55] Shimada T, Fujii-Kuriyama Y. Metabolic activation of polycyclic aromatic hydrocarbons to carcinogens by cytochromes P450 1A1 and 1B1. Cancer Sci 2004; 95: 1-6.

[56] Oberg M, Andersson PL, Johansson N, Tysklind M, Håkansson H. Multivariate modelling of polychlorinated biphenyl-induced CYP1A activity in the MH1C1 rat hepatoma cell line. Altern Lab Anim 2001; 29: 291-5.

[57] Kawajiri K, Hayashi S. The CYP1 family. In: Ioannides C, Ed. Cytochromes P450: metabolic and toxicological aspects, CRC Press: Boca Raton, FL 1996; pp. 77-97. 
[58] Moore M, Narasimhan TR, Steinberg M, Wang X, Safe S. Potentiation of CYP1A1 gene expression in MCF-7 human breast cancer cells cotreated with 2,3,7,8-tetrachlorodibenzo-p-dioxin and 12-Otetradecanoylphorbol-13-acetate. Arch Biochem Biophys 1993; 305: 483-488.

[59] Reiners JJ Jr, Scholler AP, Bischer P, Cantu AR, Pavone A. Suppression of cytochrome P450 CYP1A1 induction in murine hepatoma 1c1c7 cells by 12-O-tetradecanoylphorbol-13-acetate and inhibitors of protein kinase C. Arch Biochem Biophys 1993; 301: 449-54.

[60] Li S, Dougherty JJ. Inhibitors of serine/threonine-specific protein phosphatases stimulate transcription by the Ah receptor/Arnt dimer by affecting a stepsubsequent to XRE binding. Arch Biochem Biophys 1997; 340: 73-82.

[61] Fujita-Yamaguchi Y, Kathuria S. Characterization of receptor tyrosine-specific protein kinases by the use of inhibitors. Staurosporine is a 100-times more potent inhibitor of insulin receptor than IGF-I receptor. Biochem Biophys Res Commun 1988; 157 : $955-62$.
[62] Niggli V, Keller H. On the role of protein kinases in regulating neutrophil actin association with the cytoskeleton. J Biol Chem 1991; 266: 7927-32.

[63] Gadbois DM, Hamaguchi JR, Swank RA, Bradbury EM. Staurosporine is a potent inhibitor of P34cdc2 and P34cdc2-like kinases. Biochem Biophys Res Commun 1992; 184: 80-85.

[64] Xiao L, Caino MC, von Burstin VA, Oliva JL, Kazanietz MG. Phorbol ester-induced apoptosis and senescence in cancer cell models. Methods Enzymol 2008; 446: 123-39.

[65] Chen CC. Protein kinase C alpha, delta, epsilon and zeta in C6 glioma cells. TPA induces translocation and down-regulation of conventional and new PKC isoforms but not atypical PKC zeta. FEBS Lett 1993; 332: 169-73.

[66] Julhash U. Kazi, Jae-Won Soh Isoform-specific translocation of PKC isoforms in NIH3T3 cells by TPA. Biochem Biophys Res Commun 2007; 364: 231-7.

[67] LeHoux JG, Dupuis G, Lefebvre A. Control of CYP11B2 gene expression through differential regulation of its promoter by atypical and conventional protein kinase C isoforms. J Biol Chem 2001; 276: $8021-8$

(C) Bassi et al; Licensee Bentham Open.

This is an open access article licensed under the terms of the Creative Commons Attribution Non-Commercial License (http://creativecommons.org/licenses/by-nc/3.0/) which permits unrestricted, non-commercial use, distribution and reproduction in any medium, provided the work is properly cited. 